\title{
Revisiting Carr's Business Bluff: Opinions on the Ethics of Playing the Game
}

David S. Fowler*, Jon Musgrave***

Newberry College, South Carolina, USA; Morehead State University, Kentucky, USA

Received November 24, 2020; Accepted January 13, 2021

Abstract: This article is a response to Albert Carr's business bluff compared to a poker game article in the Harvard Business Review "Is Business Bluffing Ethical? The Ethics of Business are not Those of Society, but Rather Those of the Poker Game". Opinions are given on the ethical dilemmas which are deemed legal and acceptable in the business world by Carr.

Keywords: Business Bluff • Business Ethics • Moral Opinion

JEL Classification: A1, B3, Z1

In 1968, Albert Carr published the article, "Is Business Bluffing Ethical? The Ethics of Business are not Those of Society, but Rather Those of the Poker Game". Carr's article published in the Harvard Business Review compared and contrasted the art of the business bluff with a game of poker (Carr 1968). The article provides insights into the ethical and unethical practices that take place in the corporate world while in pursuit of closing business deals.

Bluffing is one practice utilized by commercial entities that tests the boundaries between legality and ethical business practice. This raises the question, is business bluffing ethical between competitive rivals as defined by the standards of law? For instance, there is no law as to whether bluffing can be used within the business sense. If the act is not illegal, "it can be considered in the realm of bluffing" (Beach 1985: 193). It is important to note that Carr does not attempt to define ethics of business based on society's ethical interpretation. He claims it is known that rival businesses utilize the art of the bluff and are acting in a manner which is lawful and should not be considered unethical because of legal obedience (Carr 1968). However, bluffing is considered to be ethically ambiguous and has not been accepted as standard practice within the business world (Allhoff 2003).

How bluffing is utilized, and to what extent, does the tangibility of the ethical definition emerge. The illustration of the poker game makes perfect sense. Within the strategic card game played on a green velvet table, if cognition of the bluff is not a segment of a repertoire, the probabilities for a win are diminished. The person who plays with the highest proficiency, which includes the art of the bluff, has greater opportunity to achieve victory (Friedman 1971). However, it is important to understand when it is ethically acceptable to utilize the business bluff and when to not engage the technique. Usage of the bluff or any other type of competitive advantage deployment to maliciously cause harm or gain an edge over a rival by untruthful means would be deemed unethical.

\section{Bluffing a Robust Hand}

The question to agree or disagree with Carr's stances on ethicality of the bluff in the business world is difficult to define as a simple yes or no response. Carr believes the use of bluffing as a business tactic seems to be the 
accepted norm today. However, he does not necessarily claim this approach is moral in nature. An illustration of an excellent hand in a poker game provides an insight into business application of the bluff. A royal flush, considered the top hand in poker (Poker Hand Rankings 2016) in one's possession during a game of poker, is an almost sure bet to win the hand. Of course, the player is not going to exhibit a countenance consistent of a grinning Cheshire cat. He will play with stone-faced expression to entice opponents to increase the potential winnings in the pot based on non-disclosure interpretation of his impassive appearance. In the rules of poker, this practice is not only useful, it is expected (Carson 1993).

As in poker, does one always have a necessary moral or ethical obligation to divulge a business competitive advantage? Is there a moral or ethical conflict which needs to be addressed? Obviously, without voluntarily confessing their competitive advantage, the business holding the best hand has an enormous advantage over their competitors. Competitive rivals will conduct business negotiations based on inaccurate interpretations of their competitor's supremacy. This will result in lost opportunities to adapt processes and procedures because of operating with incomplete information. The competition may also have to scramble, once the unknown hand is played, to attempt a recovery. Not only does this throw them off guard, it exhausts resources which might be deemed necessary to make an initial effective play. However, malicious intent is not exhibited by the business with the potential winning hand. It is merely practicing sound business dealing skills by not providing the competitor information to modify their business plans based on known competitive disadvantage. At no time has anything hurtful or dishonest been employed.

\section{The Inadequate Hand}

A simple deal of the cards in a game of poker provides the player with an excellent hand, good hand, fair hand, or a bad hand. A talented student of the game will not divulge which type of deal he is granted. It is a well-known fact that people who play the gambling card game for a living have heightened perception of when and how to enact the bluff (Friedman 1971). In the case of the bad hand, the poker player is at a personally perceived disadvantage after he receives the cards from the dealer. How he orchestrates his next move or moves is crucial to his success in the game. Does he fold and take an expected, however minimal, loss of the initial wager? Does he play out the hand by bluffing his way to a potential win? The variable of risk comes to the forefront as the player must make calculated decisions based on probability analysis.
Folding is the practice of stopping your participation on the hand by giving up an opportunity to win. However, by folding you are guaranteed a minimal loss of earnings. Is this acceptable in the business world? For some companies giving up the deal so easily is considered heresy, even if a learning opportunity from failure is wasted (Khanna, Guler \& Nerkar 2016). However, by folding a bad hand, nothing negative ethically has been utilized on an opposing player. The player is guaranteed a short-term loss; however, this may be recovered through enhanced trust of the competitor by exposing vulnerability through transparency (Walker 2016).

Bluffing for the win, while holding a bad deal of cards, is a well-honed skill of the poker playing professional. For instance, if the player is holding five cards which contain low numerical values, no face cards, and all different suits outside of one, and all different suits outside of one, then this would be considered a very bad hand. To win with this type of adversity would be considered a very good skill to possess. When a player is in position to win an entire round of Texas Hold-Em, and is dealt a bad hand, it could be to his advantage to play the bluff and attempt to finish the game. By using deception through non-disclosure of body language and countenance, the player may afford the opportunity to win the game as he exudes confidence to his opponents. In turn, they could crumble under pressure, and deny themselves a win by dropping out of the hand. In business, it is legal to not disclose a weakness to gain competitive advantage over a business rival. However, questions may arise as to whether this is ethical in a sense by not giving full disclosure. When failure to reveal potentially negative information could cause harm to the competition, then obviously an ethical conundrum is evident and integrity of the business could be damaged (Sacco et al. 2014). However, within the context of the business deal, bluffing a weak hand is not considered unethical by remaining within legal parameters (Carr 1968).

\section{The Cheat}

Poker presents opportunities to cheat one's opponent. An ace of spades might be hidden in a player's pocket for use during the game. When the card is played to gain advantage, then the player steps outside the boundaries of fair play. Without question, this is an illustration of cheating the game and the opposing player. Not only does the offending contestant gain unfair advantage, but he may also cause harm to the opponent and himself. For instance, if the cheating activity is discovered, the player could be expelled from the game, banished from 
patronizing a gambling establishment, or subject himself to physical harm (Walsh 2014). In the short run, the offending party may win the hand by playing the rogue card; however, his moral fiber decays and extenuating circumstances may arise which hinder his abilities to decipher right from wrong (Osler 2016).

Within the context of the business deal, the old connotation of purchasing a used car may be examined. An automobile dealer may advertise a vehicle that is three years old, has 20,000 miles, and is a one owner trade-in that was driven by an elderly woman on Sundays to attend religious services. However, the truth is the three-year-old mode of transportation had the odometer manipulated from displaying 80,000 actual miles and was previously owned by a rental agency. This is not a mere non-disclosure of negative information, it is a blatant attempt to deceive a potential customer by manipulating the truth, and a lie is presented to the unaware buying party. When a business adheres to this type of policy in dealing with customers, they are cheating the system, and ethics are thrown to the wayside. Carr (1968) addresses the cheat within the context of the corporate world, and agrees this practice in no terms adheres to the definitions of proper ethics.

\section{References}

Allhoff, F. (2003): Business Bluffing Reconsidered. Journal of Business Ethics, 45(4), pp. 283-289. https://doi.org/10.1023/A:1024103612716

Beach, J. (1985): Bluffing: Its demise as a subject unto itself. Journal of Business Ethics, 4(3), pp. 191-196. https://doi.org/10.1007/BF00705618

Carr, A. Z. (1968): Is business bluffing ethical? - The ethics of business are not those of society, but rather those of the poker game. Harvard Business Review, 46(1), pp. 143-153.

Carson, T. L. (1993): Second thoughts about bluffing. Business Ethics Quarterly, 3(4), pp. 317-341.

Friedman, L. (1971): Optimal bluffing strategies in poker. Management Science, 17(12), B-764-B-771. https://doi.org/10.1287/mnsc.17.12.B764

Khanna, R., Guler, I., \& Nerkar, A. (2016): Fail often, fail big, and fail fast? Learning from small failures and R\&D performance in the pharmaceutical industry. Academy of Management Journal, 59(2), pp. 436459. https://doi.org/10.5465/amj.2013.1109

Osler, J. E. (2016): The 4A metric algorithm: A unique e-learning engineering solution designed via

\section{Conclusion}

Carr makes valid points with bluffing and its valid convention in business. However, attention must be taken into deliberation as to when and how it is employed. Bluffing in business is not necessarily unethical as a practice; it is based on its usage. Whatever hand is dealt in the world of poker and in the environment of business, it is up to the party involved to define how it will be played. Will the bluff be utilized, and in what context? Examples of this practice may remain within the confines of legality, morals, and ethics. However, the manner the bluff is implemented defines whether it can be construed as ethical. It is possible that the legality of bluffing causes confusion as to how to implement a bluff ethically. To rectify this conundrum, it may be less perplexing to follow examples given by great philosophers and religious icons. The golden rule, "And just as you want men to do to you, you also do to them likewise" (Luke 6,31, The New King James Version), is concise and provides a foundation upon which to base ethical decisions. It is wishful thinking, however, if everyone adhered to this ancient creed and did not rely on interpretations of whether to bluff, would not the corporate world be a better place to conduct business?

neuroscience to counter cheating and reduce its recidivism by measuring student growth through systemic sequential online learning. Journal on School Educational Technology, 12(2), pp. 44-62.

Poker Hand Rankings (2016): Retrieved from http:// www.cardplayer.com/rules-of-poker/hand-rankings

Sacco, D., Bruton, S. V., Hajnal, A., \& Lustgraaf, C. J. N. (2014): The influence of disclosure and ethics education on perceptions of financial conflicts of interest. Science and Engineering Ethics, pp. 875-894. https://doi.org/10.1007/ s11948-014-9572-6

Walker, K. L. (2016): Surrendering information through the looking glass: Transparency, trust, and protection. Journal of Public Policy \& Marketing, 35(1), pp. 144-158. https://doi.org/10.1509/ jppm.15.020

Walsh, J. (2014): Poker crime logs - Man shoots, kills his own brother for cheating at poker. Retrieved February 5, 2017, from http://f5poker.com/pokernews/2014/11/19/poker-crime-logs-man-shootskills-his-own-brother-cheating-poker-/ 